\title{
Dick Gregory and Activist Style: \\ Identifying Attributes of Humor necessary for Activist Advocacy
}

\author{
Author: \\ Jonathan Paul Rossing \\ Published in Argumentation and Advoacy.
}

This is the author's manuscript of the article published in final edited form as:

Rossing, Jonathan P. (2013). Dick Gregory and Activist Style: Identifying Attributes of Humor Necessary for Activist Advocacy. Argumentation and Adocacy, 50(2), 59-71. 


\begin{abstract}
Human rights advocacy is often austere, if not funereal. Nevertheless, humorists have long engaged human rights activism through their art. Against claims that humor weakens action or conservatively maintains the status quo, this essay argues for humor as necessary element in human rights activism. At its best, humor awakens communities by providing new perspectives on reality and sharpening understandings of injustice. It provokes dialogue and action and humanizes all parties in a struggle. This paper explores humor as a necessary, if not sufficient, component of an activist political style through a case study of comedian and activist Dick Gregory. Using evidence from Gregory's performances and speeches as well as public discourse about Gregory, this paper establishes humor as an integral characteristic of an activist political style.
\end{abstract}

Keywords: humor, political style, activism, race/racism, Dick Gregory 


\section{Dick Gregory and Activist Style:}

\section{Identifying Attributes of Humor necessary for Activist Advocacy}

Denouncing oppression or advocating for human rights infrequently evokes levity. Social justice advocacy is often austere, if not funereal. Tragic injustices often vivify the stakes of human rights struggles, consequently rendering humor almost unfathomable. Imagine cracking jokes about Emmett Till after his murder in 1955 or riffing on Matthew Shepard's slaughter in 1998.

Nevertheless, humorists regularly use their art to advance serious causes, even amidst tragedy. Literary satirists Jonathan Swift and Mark Twain typify humor in service of social justice. Bert Williams, an African American vaudeville artist who performed with the Ziegfeld Follies, subtly critiqued racism through minstrelsy at the turn of the $20^{\text {th }}$ century. Following the holocaust, Jewish humorists critiqued the moral failings of the complicit and fostered solidarity among survivors. Contemporary examples of humor bent toward social justice include Margaret Cho’s feminist, queer, anti-racist stand-up comedy and W. Kamau Bell's sharp socio-political comic criticism.

In his work on political styles, Robert Hariman (1995) argued, "To the extent that politics is an art, matters of style must be crucial to its practice;" in short, “[P]olitical experience is styled" (pp. 2-3, emphasis in original). Human agents negotiate power relations, knowledge, and social-political identity with "a coherent repertoire of rhetorical conventions," "habitual communicative practices," "aesthetic reactions," and "compositional techniques" that guide behavior, inform socio-political action, influence decision-making, distribute power, mold perceptions, shape attitudes, and mediate reality (Hariman, 1995, pp. 2-4, emphasis in original). In short, style and politics interweave. In this essay I continue the investigation of political styles to explore a particular set of conventions associated with an activist style of advocacy. Insofar as communities worldwide continue to struggle for justice, humanization, and recognition, critical scholars must identify discursive practices that constitute an activist political style. At its best, humor sharpens understanding of injustice, brings 
communities together, and provokes dialogue and action (e.g. Hutcheon, 1994; Mintz, 1988;

Nachmann, 2003; Rossing, 2011). Therefore, I argue that humor figures as a necessary, if not sufficient, element of an activist style of advocacy. Said differently, activism necessarily takes place with a comic sensibility.

Comedian and activist Dick Gregory, who performed at the apogee of the United States Civil Rights Movement, offers an illustrative case study for understanding humor as a component of an activist style. Dick Gregory's career as both activist and humorist highlights particular habits, attitudes, and conventions of an activist style, thereby offering what Hariman (1995) called a "mirror text” (p. 5, 177). Furthermore, Gregory's work provides guidelines for recreating similar patterns in political action and thus, invites critical interrogation of the functioning of such a political style in U.S. racialized public culture. This essay begins with an overview of scholarly connections between humor and activism with an emphasis on humor oriented toward racial justice. Next, a brief biography of Dick Gregory explains why his career uniquely suits him for a consideration of the intersection of activism and humor. Then the argument proceeds in three parts. First, comically styled advocacy overcomes barriers to identification and powerfully unites communities in understanding and purpose, humanizing all parties in the struggle. Second, humor imbues activism with a creative spirit necessary to awaken new perspectives on reality and to challenge the status quo. Third, humor fosters hope required for optimistic progress in the face of daunting obstacles. In conclusion, I consider limitations and opportunities for humor in advocacy for racial justice.

\section{Activism and Humor}

In Attitudes toward History, Kenneth Burke (1984) famously articulated the comic corrective. The "comic frame" is the "methodic view of human antics as a comedy, albeit as a comedy ever on the verge of the most disastrous tragedy" (p. iii). This frame encourages a charitable attitude towards others; that is, it positions fellow community members as social animals inescapably 
susceptible to folly and fallacy. When we err or when others deceive us, the comic frame helps people avoid cynicism or hostility in favor of self-study and self-reflection. Consequently, the comic frame helps people recognize foibles and learn from mistakes. Said otherwise, the comic frame "considers human life as a project in "composition" and "offer[s] maximum opportunity for the resources of criticism" (p 173). In short, "criticism had best be comic" (p. 107). Following Burke's observation, I argue that activist advocacy had best feature humor as a characteristic attitude.

My argument joins a body of scholarship that articulates humor and activism. Rhetorical scholars have explored the role of humor and the comic frame in social movements and social change. A. Cheree Carlson (1986), for example, analyzed Mohandas Gandhi’s leadership during the Indian Civil Rights movement. His non-violent strategies and tactics epitomized styles associated with the comic frame such as a charitable performance of identification. Adrienne Christiansen and Jeremy Hanson (1996) analyzed ACT UP's (AIDS Coalition to Unleash Power) direct action protests at the height of the AIDS crisis in the United States. They illustrated how ACT UP employed a comic frame to change perceptions of gay men and to promote moral action in response to the AIDS epidemic. More recently, scholars such as Amber Day (2011) have examined humor in political protest and dissent. News satirists such as Jon Stewart, Stephen Colbert, The Onion, and documentarians such as Michael Moore employ humor to intervene meaningfully into political conversations and redirect public debates. For example, the "Rally to Restore Sanity and/or Fear" in 2010, hosted by Stewart and Colbert, challenged polarized, biased political media coverage and sought to shape national attitudes about political partisanship in Washington, DC (Jones, Baym, \& Day, 2012).

Ample research also considers the use of humor in advocacy against racial injustice. From slavery to the present, an "assertive and openly critical" humor emerged from the black community and predominantly black social gatherings to subvert racial norms, challenge injustices in mainstream 
society, and provoke social protest (Watkins, 1994, p. 39). Such humor features connections to the African American rhetorical tradition of signifying, a practice featuring playful language games and tropes that displace, revise, and call attention to meaning (Gates, 1988). As such, African American humor may not always appear as a direct protest against the socio-political structures of racism and their material manifestations; however, this humor often brings to consciousness the subtle ways racism influences identity, social relations, opportunities, and more (Carpio, 2008; Timmerman, Gussman, and King, 2012). Moreover, humorous discourse creates non-threatening spaces in which people challenge and subvert ideological presuppositions (Haggins, 2007). Although such humor has a well-documented history in the African American tradition and even in African trickster tales (Gates, 1988; Watkins, 1994), this humor is not exclusively the work of Black artists. For instance, Stephen Colbert, a White comedian with a satirical news program on Comedy Central, undermines postracial logics and strategically highlights Whiteness and White privilege in ways that could draw attention toward persistent racial injustices (Rossing, 2012).

I mean not to overstate the power of humor in social transformation. Indeed, scholars have warned about the limitations of political humor for social change. Polysemy consistently limits humor. Audiences may find their biases and political ideologies confirmed rather than refuted when enjoying satire or irony (Baumgartner \& Morris, 2008; Gring-Pemble \& Watson, 2003). Arguably the greatest anxieties about humor arise from the possibility that it naturalizes oppressive social difference and distinctions (e.g. Anderson, 2011; Park, Gabbadon, \& Chernin, 2006). Prior cultural knowledge also hinders humor and exacerbates the potential for multiple meanings. If audience members lack cultural awareness of the issues at stake in humor, they are less likely to enjoy or accept the comedic messages (Banjo, 2011).

Recognizing humor alone will not transform society, I nevertheless argue that attitudes and conventions associated with humor must figure prominently in socio-political activism. My 
argument neither focuses on effects of activist humor nor seeks to define the intentions or meanings of such humor. Rather, I am interested in the way humor plays a prominent role in the performative guidelines and in the repertoire of attitudes and behaviors necessary for social justice advocacy. Against this backdrop of scholarship on activism, protest, race, and humor, I consider the career of Dick Gregory to argue for humor's role in an activist style.

\section{Comedian and Activist Dick Gregory}

The 1950s and 1960s witnessed an eruption of comic criticism in U.S. public culture as satirists skewered political unrest, foreign affairs, civil rights issues, and other important public issues (Kercher, 2007; Nachman, 2003). During this comic boom, black comedians addressed problems of racism, integration, segregation, and ongoing civil rights struggles. Those routines, however, played principally to black audiences in black theaters, particular in the Theater Owner's Booking Association also known as the "Chitlin Circuit" (Foxx \& Miller, 1977; Watkins, 1994). Black comedians popular with white audiences retained characteristics of minstrel personas such as Jim Dandy or Stepin' Fetchit that white audiences had come to expect. Timmie Rogers, for example, popularized a flashy Zoot Suit persona, but when he donned a suit and tie and commented on current affairs, consistent with an intellectual persona popularized by comedians such as Mort Saul, his contract was quickly terminated.

In the midst of this comic boom, Richard "Dick" Claxton Gregory emerged at the height of the civil rights movement. He almost missed his big break. In January 1961, Gregory lived in Chicago and was struggling to launch his comedy career when the famous Playboy Club called. The lead entertainer had fallen ill and the manager wanted Gregory to replace him. When he arrived at the club, however, the management tried to turn him away because a group of Southern executives had booked the club. Gregory insisted he perform, and he won the crowd over. The performance earned Gregory a long-term engagement at the Playboy Club, and consequently launched him into 
the national spotlight. Gregory rose to stardom as the first African American stand-up comedian to play to white audiences with satirical performances that skewered injustices of racism. He played the major comedy clubs in New York, San Francisco, and Las Vegas, which remained predominantly segregated. He became the first black guest invited on Jack Paar's Tonight Show. One month after his premier, Time magazine reported, "With intelligence, sophistication, and none of the black-voice buffoonery of Amos 'n' Andy, ... [Gregory] has become the first Negro comedian to make his way into the nightclub big time" ("Humor, Integrated," p. 69). Following his rise to the national circuit, the New York Times celebrated Gregory's ability to "hold his own in the ranks of the bright, young, intellectually oriented, wittily topical, stand-up comics" (Gelb, 1961, p. 34).

Gregory integrated comedy clubs and paved the way for performers like Godfrey Cambridge, Bill Cosby, and Richard Pryor; nevertheless, he is remembered more for his human rights initiatives and dietary activism. Shortly after gaining celebrity, Gregory began turning down comedy club offers in favor of more direct action. He involved himself heavily in the civil rights movement by attending marches, sit-ins, and rallies throughout the South, forming friendships with Rev. Dr. Martin Luther King Jr., Medgar Evers, and Malcolm X. He received death threats for his activism and his non-violent protests led to multiple arrests. Gregory ultimately expanded his activism beyond the Civil Rights Movement. He became a proponent of raw food and veganism, staged multiple hunger strikes, and intervened in the Iranian hostage crisis. When advocating for Native American fishing rights in Washington, Gregory explained "I hope I'm never accused of fighting only for Negro rights. I'm fighting for buman rights" (Lee, 1966, p. 487).

Despite leaving the stage spotlight, humor remained an integral component of his activism. As one critic described, Gregory “is more comical when he's serious than the rest of the funnymen when they're trying to be funny" (Smith, 1967, p. 13). In over five decades of newspaper and magazine reports on Gregory's various political actions, he is constantly referenced as a "comedian 
and activist" or "social activist" or "political activist" or "rights activist." In other words, even off the stage, he employed a comic frame as he engaged in activist efforts. Humor remained his guiding orientation and established the conventions for his day-to-day actions. For these reasons, Gregory models humor as a necessary feature for an activist style of advocacy. In the following sections, I call upon Gregory's performances, autobiography, and interviews to identify three ways humor is a necessary dimension of an activist style.

\section{Humanizing Identification: "Comedy as Friendly Relations"}

Human rights activism strives to end dehumanizing practices and to gain full recognition of humanity for all. In Political Style, Hariman (1995) argued, "[V]alues can only be taken seriously once performed successfully" (p. 10). Thus, insofar as a dominant value of activism is humanizing identification, an activist style must actualize this value through performance. An activist style must successfully overcome the problem that rhetorical educators have long addressed: "how to orchestrate differences in a manner that makes concerted action possible; how to form a genuine 'we' out of diversity" (Poulakos, 1997, p. 3). Said otherwise, activists must "develop practices that support vigorous arguments about political disagreements by sustaining the relationships that make it worthwhile to argue with others in the first place" (Allen, 2004, p. 87). A strong sensibility toward identification, then, is essential for an activist style. The repertoire must include attitudes and performances that construct commonality in the context of difference.

Humor cultivates identification among different groups through a humanizing attitude. Such an attitude impels people to accept imperfections. They must embrace a capacity for both good and evil and their tendency to (un)consciously promote both justice and injustice. As Burke (1984) noted, the comic frame celebrates people's humanity, their faults and foibles as well as their successes. The charitable attitude associated with humor avoids both outright vilification and heroification, but instead "promotes the realistic sense of one's limitations" (p. 107). James Kastely 
(1997) identified this humanizing comic attitude in the comedy of Aristophanes and celebrated the role of this humanizing spirit: "If democracy is to flourish, it can do so only by a solid grounding in the way people are and not in an idealistic conception of human nature” (p. 41).

Gregory's breakout performance at the Playboy Club demanded this humanizing sensibility. He faced a potentially inhospitable scenario as a black man playing to white Southern business men with material on racial injustice. Gregory faced a monumental challenge: connect with the audience and arouse laughter despite a socio-political context that might invite coolness at best, hostility at worst. As a comedian he had to impress upon his audience the seriousness of the issues facing the nation without violating the conventions of stand-up comedy or the decorum of the comedy club. As a racial justice advocate he had to defy both the cultural authority of southerners who embraced segregation as a way of life and the moral authority of northerners who might imagine themselves ethically superior to the problems of the south. Thus, Gregory required a sophisticated performance that would forge identifications with the audience and gain their trust. At the same time, he could not provoke defensiveness, offend the audience, or deeply wound their pride lest he lose the standing to address them generated by the occasion and context. Gregory savvily performed humanizing identification on two registers: first through strong humility, and then with a charitable orientation that resisted audience vilification.

In his autobiography, Gregory explained that he learned at an early age the importance of laughing at oneself as a way to perform humility. As one of the skinniest, poorest children in his community, Gregory encountered frequent torment and teasing. Under these conditions, he learned that humility through humor, smiles, and laughter forges powerful identifications. Recognizing that other children in the neighborhood would laugh anyway, he discovered that making the jokes first would sway his aggressors toward his side. "Once you get a man to laugh with you," he explained, “it’s hard for him to laugh at you” (Gregory \& Lipsyte, 1964, p. 41). An experience before his big 
break at the Playboy Club reinforced this lesson. In 1959, Gregory performed at the Roberts Show Club, a premier black entertainment venue in Chicago. He opened for the main attractionsperformers such as Sammy Davis, Jr. and Nipsey Russell. At the time, Davis and Russell played to majority white audiences who ventured to Chicago's predominantly African American south side just to see these stars. At the Roberts Show Club, audiences roared in delight at Russell's racial comedy. However, following his success at Roberts, Russell failed to win over white audiences at white night clubs: his performance fell flat. Gregory reasoned that white audience members stood outside their comfort zone at Roberts. Black artists possessed an advantage at Roberts because white audience members sought to relieve their tension and demonstrate their difference from other white people. "A white man will come to the Negro club," Gregory explained, "so hung up in this race problem ... that anything the comic says to relieve his tensions will absolutely knock him out" (Gregory \& Lipsyte, 1964, p. 131). However, in white-owned night clubs, white audiences remained comfortably secure: they "didn't have to laugh at racial material that [they] didn't want to hear" (Gregory \& Lipsyte, 1964, p. 131). Such an environment required a black artist to cultivate the right attitude in order to prevent a failed performance.

Gregory determined that when his time came to take the stage "in their neighborhood" he would overcome the pity, hatred, and disrespect that kill laughter. Just as he forged connections with his schoolmates in St. Louis, Gregory would approach the audience with humility before they could form an opinion contrary to his purposes. He explained:

I've got to act like a star who isn't sorry for himself- that way, they can't feel sorry for me. I've got to make jokes about myself, before I can make jokes about them and their societythat way, they can't hate me. Comedy is friendly relations. (Gregory \& Lipsyte, 1964, p. 132) This humility differed from insecurity; rather, it required confidence to position oneself as the butt of a joke. In short, Gregory sought to gain respectability and to cultivate identification through 
comedy; his performance of humility and fallibility allowed him to work toward these goals. This sensibility, what Gregory called "one of the greatest lessons in show business," (Gregory \& Lipsyte, 1964, p. 130) is essential to an activist style.

A charitable attitude toward the audience represents the second characteristic of humanizing identification. The ultimate test of this sensibility arrives when a heckler disrupts the show.

Gregory explained, "Handling a heckler just right is very important to a comic" (Gregory \& Lipsyte, 1964, p. 133). However, the racial context complicated Gregory's need to respond to hecklers with even greater sensitivity. As a black comedian entering white comedy clubs, Gregory would invariably encounter a hostile audience member who not only disrupted the act but also hurled hatred at him. In particular, he anticipated the inevitable performance when a white man would call him a nigger. The response to such a situation might determine Gregory's success. Too much vitriol would turn the audience against him. Too weak a response would diminish the entertainer's respectability and control, and thus, the audience would pity the performer. Moreover, if a heckler shouted a racial epithet, audience members would experience discomfort. Without quickly defusing the situation, the audience would associate the comedian with that discomfort. Gregory explained, "That split second is all the difference between going on with the show or letting the customers feel pity and a little resentment for the entertainer who got put down" (Gregory \& Lipsyte, 1964, p. 133). Gregory asked his wife to call him a "nigger" at the dinner table so he could practice retorts, but his reactions always appeared "a little bitter, a little evil:" an improper attitude orientation for identifying with the audience and successfully advocating for racial justice. He believed a sophisticated answer required coolness. First, performing such cool confidence denies the audience the opportunity to pity the entertainer. Second, this coolness prevents the audience from experiencing anger and hostility, which would foreclose opportunities for identification. 
Gregory developed humanizing retorts for these situations. When he performed at a working-class white club to laborers and factory workers, an audience member called him a nigger mid-performance. "You hear what that guy just called me?" Gregory asked. "Roy Rogers' horse. He called me Trigger!” Another common retort:

My contract reads that every time I hear that word, I get fifty dollars more a night. I'm only making ten dollars a night, and I'd like to put the owner out of business. Will everyone in the room please stand up and yell nigger? (Gregory \& Lipsyte, 1964, pp. 134-135)

In both retorts, Gregory maintained his confident humility. He refused to ignore or retreat from the threat, opting instead for direct confrontation. Yet, his confrontation conveys both humbleness and charity toward his audience. In the first, he plays the fool by presumably mistaking the epithet for a horse's name. In the second, he becomes a sucker for punishment by inviting the audience to continue the harassment. His coolness prevented such aggression from rankling him and he framed himself as ultimately profiting from continued aggression. This cool, confident humility complemented his charitable orientation. He would not attack the heckler, nor would he lump the entire audience together as racists. He directed no anger toward the audience, thereby creating stronger possibilities for connection and continued engagement.

With a blend of humility and charity, Gregory thrived. These stylistic sensibilities enabled Gregory to participate in socio-political conversations about race as an advocate for civil rights. In the words of one critic:

If there is one key to Mr. Gregory's success, it is probably his ability to examine the foibles of both the black and white races without a trace of rancor or pretension and without any stooping or loss of dignity. (Gelb, 1961, p. 34) 
He cultivated a "brotherhood [sic] of humor" and forged strong identification at a time of division ("Humor, Integrated"). The liner notes on his first album, Dick Gregory in Living Black and White, read:

No matter what his subject, Dick Gregory will not make you angry. Nor can the most vitriolic race-baiter anger him. This record carries no message, unless the message is this: There is no problem so serious that it cannot be leavened with humor. (as cited in Nachman, 2003, p. 484)

In short, Gregory advocated for racial justice with a humanizing mixture of levity and seriousness that allowed him to identify with his audience and make himself relatable.

\section{Creative Intervention}

Humor's inventive spirit represents a stylistic sensibility suitable for activism's transformative impulse. Lawrence Mintz (1988) suggested humor defines "new values, attitudes, dispositions, hopes, fears, expectations, and new behavior models to laugh at and to laugh with" (viii). Moreover, humor allows people to confront "virtually everything that is important to us in ways that make us understand ourselves and our society more thoroughly, more deeply, more meaningfully" (Mintz, 1988, viii). Furthermore, humor creates space for a potentially disruptive cacophony of voices. Joseph Boskin (1997) described the "people’s humor" as a style with a "prodding presence ... crisscrossing within and between classes and ethnic groups" that contests, exposes, challenges, troubles, and questions public life from different subject positions (p. 204). Richard Lanham (1976) argued when people put too much stock in current reality and fail to recognize alternative ways of being or knowing, then a "comic counterpressure" helps counteract such "pathological" rigidity. Humor reintroduces "rich resources of play" that allow people to imagine new realities (p. 31-32). These characteristics of humor figure prominently in African trickster tales that inspire African American humor and literature (Gates, 1988; Hyde, 1998). Trickster figures are boundary-workers 
and crossers who introduce elements such as indeterminacy, open-endedness, ambiguity, disruption. As such, their playful creativity often counters the status quo and encourages people to envision new possibilities. For this reason, Gates (1988) connects the trickster tradition to the practice of signifying in African American literature arguing that these playful rhetorical maneuvers create narrative space for the Black Experience.

Gregory's routines display humor's potential to create possibilities for new cultural norms and social understanding. He sought to transform his audiences' understanding of race and racial politics and injustices. His routines featured playful attacks against the Klan and segregation, emotional appeals about the immorality of racism, and agile maneuvering around cultural taboos. One critic described Gregory's performance as "a kind of immemorial, unchurched racial lament, a cataloguing of wrongs, a reading of indictments. The sterner the indictment, the more convulsed are his listeners” (Millstein, 1961, p. 37). With trickster-like playfulness, Gregory's jokes illustrate the way humor invites new perspectives on the familiar using tactics such as doubled-meanings and shifting attention patterns.

In his breakout performance at Chicago's Playboy club in 1961, Gregory regaled his white, Southern business audience with a story about his visit to the South. Gregory explained that restaurant owners turned him away saying, “We don’t serve coloreds here.” Gregory responded, “That's fine 'cause I don't eat them! I'll have the fried chicken.” The joke's set-up encourages the audience to look through language to a familiar, stable meaning. Given the cultural context, the audience would expect a restaurant to deny Gregory service, and therefore, the audience had no reason to understand Gregory's statement differently. However, this opening misdirection forces the audience's attention in one direction only so Gregory could shift their attention in another direction. Quipping that he does not eat "coloreds," he unsettled stabile meanings and offered a new vantage point on familiar language practices. To understand the humor, the audience must 
oscillate from the stable, expected meaning back to the language itself in order to look once again at the word "serve." The punchline required shifting attention from one meaning- "to provide services"- to another- "to offer a type of food on a menu." Gregory moved the audience to the absurd realm in which black Americans might be served as food. Pushing the meaning of "serve" toward absurdity destabilizes the original meaning; suddenly both practices, including the common sense notions, become preposterous. The joke rebuts segregation by turning the tables on a demeaning practice so that it appears ludicrous.

In another biting social critique, Gregory told audiences, There's no difference between the North and the South. In the South they don't care how close I get so long as I don't get too big, and in the North they don't care how big I get as long as I don't get too close. (Humor, Integrated, 1961, p. 7)

The chiasmus in his punch line generates both the comic moment and the insightful perspective. Gregory refuted audience expectations about different racial attitudes and experiences in the North and South with an inversion that underscored the common experience of racism across its regional manifestations. Drawing this parallel between forms of racial animus, Gregory invites audiences to assume a broader perspective on the problem of race, and consequently, creates possibilities for audience members to see themselves implicated in the problem.

Throughout his performances, Gregory used humor to animate serious consideration of the problems, complexities, and contingencies in a society marred by racial injustice. He drew critical attention to overlooked experiences and perspectives. These capabilities further position humor as an important feature of an activist style. Advocates seeking to revise common sense and dominant norms may benefit from a performance featuring creative language revisions and trickster-like strategies that expose new ways of seeing and allow for the interplay of perspectives.

\section{Hope and Optimism}


Humor is not simply a strategy for identification, framing, and constructing new perspectives. Because humor provides hope amidst often grim circumstances, humorous sensibilities most suit an activist style. People overwhelmingly confront their most threatening, most uncomfortable thoughts and realities through humor (Freud, 1960). Cultivating hope through humor must not suppress the pain or rage injustice evokes. Rather, humor counterbalances these emotions that equally drive the need for change. Insofar as activism strives for a better world, one must remain optimistic for the imagined future. Paulo Freire (2003) argued hope is a necessary condition for social transformation: attempting social change without hope is futile. Therefore, an activist must:

unveil opportunities for hope, no matter what the obstacles may be. After all, without hope there is little we can do. It will be hard to struggle on, and when we fight as hopeless or despairing persons, our struggle will be suicidal. (Freire, 2003, p. 9) Hope creates consciousness of the future and new possibilities. That future orientation complements both the drive to identify with others and the impulse to creative intervention.

Gregory received an education on the connection between hope and humor from his mother while growing up in St. Louis. The family lived on welfare, often scrambling for food and clothing. Yet, his mother wore a smile at all times, despite their living circumstances, her health conditions, and long work hours seven days a week. She reminded her kids, 'We ain't poor, we're just broke." For Gregory, a clear lesson emerged: "Poor is a state of mind you never grow out of, but being broke is just a temporary condition" (Gregory \& Lipsyte, 1964, p. 25). She stayed "good and beautiful in her soul" because she found hope in laughter. More important, Gregory's mother taught her children "to smile and laugh when the house was dark and cold" and when they were hungry (Gregory \& Lipsyte, pp. 27-28). Gregory summarized this principle lesson: everyone "has 
two ways out in life-laughing or crying. There's more hope in laughing” ( Gregory \& Lypsyte, p. 25).

Humor and laughter mark the difference between living to laugh again or falling into defeat. He explained on his album Dick Gregory in Living Black and White, "You got to learn how to make the bad things pleasant. 'Cause I believe one day this'll all be over'" (as cited in Nachman, 2003, p. 486). He conveyed this sensibility in his material. For example:

They asked me to buy a lifetime membership in the NAACP, but I told them I'd pay a week at a time. Hell of a thing to buy a lifetime membership, wake up one morning and find the country's been integrated. (Gregory \& Lipsyte, 1964, p. 132)

Performances fueled by such a future-focused orientation bespeak the hope necessary for ongoing struggle. Gregory's attitude epitomizes an attribute Watkins (1994) identified in Black humor: “it nimbly moves on to a vision of a brighter future or insistently counters the disparaging picture at hand" with a more positive frame (p. 39). Indeed, this characteristic of humor figures prominently in an activist style. One must perform with sensitivity toward creating hope for a better future.

\section{Humanizing Activist Style}

Humor provides a repertoire of skills, habits, and attitudes that might inform social justice advocacy. Dick Gregory's career as a comedian and activist presents a compelling case for humor as a necessary, if not sufficient, characteristic for an activist style of advocacy. Gregory's humor emphasizes three distinct features of a comic sensibility that figure as components for an activist style. Specifically, humor promotes connection amidst difference, creative revisions of the familiar, and a future-oriented sensibility suitable for social change. In conclusion, I consider the implications and possibilities for this activist style infused with sensibilities of humor in relation to contemporary advocacy for racial justice. 
In the fifty years since Dick Gregory's rise to stardom, racial realities have transformed and yet ideological and institutional commitments that maintain white privilege and racial oppression remain deeply rooted in in U.S. public culture. Moreover, ongoing efforts to uproot racism regularly meet resistance in the form of postracialism, neoliberalism, and other discourses that reject material realities of race and deny both the consequences of our racial history and our complicity in maintaining racism. In short, the "racial contract" remains firmly in place "by virtue of its unwillingness to be named" and the unwillingness of white Americans to acknowledge and repudiate it (McPhail, 2004, p. 397). For these reasons, McPhail (2002) argued, [T] here is little that African Americans or other people of color can do to convince people of European descent to collectively call into question the power and privileges they enjoy in the present that are embedded in the racial past. ( $p$ 198)

Elsewhere I have argued that humor offers an antidote to postracial discourses and other efforts to deny the history of racism (Rossing, 2014). Critical race humor carries both the possibility of exposing racial realities through frank truth-telling and the potential to activate spaces to talk about race. My emphasis here on the stylistic conventions of humor extends this conversation and introduces possible pathways for addressing McPhail's (2004) second concern: white responses to racial truth-telling that feature "a certain kind of blindness, a dialogic deafness, a discursive dumbness" (p. 398). Because humor often features a humanizing spirit of humility and charity, it is a necessary component for racial justice advocacy that must overcome resistance to racial truths. Indeed, Dick Gregory both exposed racial truths from his experience and prevented white audiences from rejecting his advocacy and truth-telling as too strident. Through humor he exposed racial realities "without making [white] people feel tortured or uncomfortable" while allowing them to "have some clarity about the stupidity of segregation" (Williams, 2000). In short, he "made you an ally and not an adversary" (Nachman, 2003, p. 486). Thus, an activist style characterized in part by 
sensibilities of humor has the potential to be less confrontational and more invitational, thereby opening up possibilities for white Americans in particular to reject customary responses of innocence or denial and to commit to projects of racial justice. To be clear, I am suggesting neither that oppressed groups should hide rage under the veil of humor nor that privileged, dominant groups should be coddled and protected from discomfort. Humor may be a viable outlet for rage and critical truth-telling through humor will likely unsettle and provoke audiences. Amidst these emotions and reactions, however, the humanizing impulse of humor may help create pathways for identification that keep audiences engaged and connected to the messages of social justice advocates. Gregory's humor-oriented activism throughout his five decade involvement in social justice and human rights issues may represent a case par excellence for understanding humor as an essential component of an activist style. Hariman (1995) notes however, "An account of political style should be more than a handbook of techniques" (p. 7). Thus, I intend the characteristics of humor detailed here neither to constitute a rigid prescription for social justice advocacy nor to represent a comprehensive account of an activist style. Rather, these conventions and performances inflected by humor are open to "continual improvisation, individual distinction, and highly personal identification" (Hariman, 1995, p. 11). To see this style animated in other contexts, one might consider an artist like the late George Carlin who disrupted conventional wisdom with routines on American politics, religion, capitalism and corporate control, and more. More recently, comedians Ahmed Ahmed, Maz Jobrani, Aron Kader, and Dean Obeidallah have waged "warfare by humorous means" on Arabaphobia and Isalamophobia. These humorists foster new identifications where the war on terror has created ambiguous, destructive divisions between "us and them" (Poniewozik, 2007). Likewise, in the face of tragic shootings of young black men such as Trayvon Martin, Sean Bell, and Oscar Grant, comedians including W. Kamau Bell, Dave Chappelle, and Sarah Silverman employ humor to speak out against racial profiling and to cultivate hope that a legacy of racism will 
subside. These humorists, just as Dick Gregory before them, reproduce these characteristics of an activist style anew. These artists reproduce and improvise upon the conventions outlined here, yet central to these performances are the characteristics that mark humor as an important component of an activist style: humanizing others and fostering connections across difference that create possibilities for change in relation to serious socio-political issues and fostering hope for a better future.

Dick Gregory's own narrative complicates the argument presented here as Gregory maintained a division between the comedy club stage and the front lines of action. He treated his time as a stand-up comedian as a separate enterprise, divorced from real activism. He argued in his autobiography,

Sure I could stay in the night clubs and say clever things. But if America goes to war tomorrow would I stay home and satirize it at the Blue Angel? No, I'd go overseas and lay on some cold dirt, taking the chance of dying to guarantee a bunch of foreigners a better life than my own Momma got in America. (Gregory \& Lipsyte, 1964, p. 159-160)

For Gregory, comedy was not direct action, but an escape from the action. Entertainment venues seemed too far removed from the central sources of conflict. For this reason, he gave up lucrative contracts and cancelled appearances in favor of marches and protests, and his career as a premiere stand-up comedian was short-lived. Gregory's view, however, does not invalidate the argument presented here. It preserves the possibility that a comic posture-humor as a stylistic sensibilityremains a vital component of activist efforts. Gregory was not a comedian-turned-activist but an activist who embodied humorous styles and attitudes in every facet of his performance. Even as Gregory moved away from show business—-first toward civil rights activism, then health issues and humanitarian concerns — he retained the balance between seriousness and levity (Nachman, 2003). Indeed, political styles easily transform and transport "without exclusive sense of locale, or context, 
or audience" (Hariman, 1995, p. 12). In other words, the point is not that comedy clubs serve as the front lines of social justice advocacy, but rather that the sensibilities and conventions associated with humor contribute to a style of advocacy that might direct activist speech and conduct in many contexts. Although Gregory might insist that one cannot perform activism in the comedy club, I insist that the performance of activism, wherever the site, demands comic sensibilities. 


\section{Author Note}

Jonathan P. Rossing, PhD, Department of Communication Studies, Indiana University Purdue University, Indianapolis (IUPUI). A previous version of this paper was presented at the 2012 National Communication Association convention in Orlando, Florida. The author thanks Professors Kristen Hoerl, Casey Kelly, Kristin Swenson, Mark L. McPhail, the anonymous reviewers, and Editor Harry Weger, Jr. for their valuable feedback on this essay. Correspondence concerning this article should be addressed to Jonathan Rossing, 425 University Blvd, Department of Communication Studies, Cavanaugh Hall Room 309, IUPUI, Indianapolis, Indiana, 46202. Email:jrossing@iupui.edu 


\section{References}

Allen, D. (2004). Talking to strangers: Anxieties of citizenship since Brown v. Board of Education. Chicago, IL: University of Chicago Press.

Anderson, K. (2011). "Rhymes with blunt": Pornification and U.S. political culture. Rhetoric and Public Affairs, 14(2), 327-368. DOI: 10.1353/rap.2010.0228

Banjo, O. (2011). What are you laughing at? Examining White identity and enjoyment of Black entertainment. Journal of Broadcasting and Electronic Media, 55(2), 137-159. DOI:

$10.1080 / 0883815120.11 .570822$

Baumgartner, J. C., \& Morris, J. S. (2008). One ‘nation' under Stephen? The effects of The Colbert Report on America's youth. Journal of Broadcasting and Electronic Media, 52(4), 622-643. DOI: $10.1080 / 08838150802437487$

Boskin, J. (1997). Rebellious laughter: People's bumor in American culture. Syracuse, NY: Syracuse University Press.

Carlson, A. C. (1986). Gandhi and the comic frame: 'Ad bellum purifcandum'. Quarterly Journal of Speech, 72(4), 446-455. DOI: 10.1080/00335638609383787

Carpio, G. R. (2008). Laughing fit to kill: Black humor in the fictions of slavery. New York, NY: Oxford University Press.

Christiansen, A. E., and Hansen, J. J. (1996). Comedy as a cure for tragedy: ACT UP and the rhetoric of AIDS." Quarterly Journal of Speech, 82(2), 157-170. DOI: $10.1080 / 00335639609384148$

Day, A. (2011). Satire and dissent: Interventions in contemporary political debate. Bloomington, IN: Indiana University Press.

Freud, S. (1960). Jokes and their relation to the unconscious (J. Strachey, editor and trans). New York, NY: W. W. Norton. 
Foxx, R., \& Miller, N. (1977). The Redd Foxx encyclopedia of Black humor. Pasadena, CA: Ward Ritchie Press.

Freire, P. (2003). Pedagogy of hope: Reliving Pedagogy of the Oppressed. Trans. R. R. Barr. New York, NY: Continuum.

Jones, J. P., Baym, G., and Day, A. (2012). Mr. Stewart and Mr. Colbert go to Washington: Television satirists outside the box. Social Research, 79(1), 33-60.

Gates, H. L. (1988). The signifying monkey: A theory of African American literary criticism. New York, NY: Oxford University Press.

Gelb, A. (1961, March 20). Comic withers prejudice cliches. New York Times, p. 34.

Gregory, D., \& Lipsyte, R. (1964). Nigger. New York, NY: Pocket Books.

Gring-Pemble, L., and Watson, M. S. (2003). The rhetorical limits of satire: An analysis of James Finn Garner's Politically Correct Bedtime Stories. Quarterly Journal of Speech, 89(2), 132-153. DOI: $10.1080 / 00335630308175$

Haggins, B. (2007). Laughing mad: The Black comic persona in post-soul America. New Brunswick, NJ: Rutgers University Press.

Hariman, R. (1995). Political style: The artistry of power. Chicago, IL: University of Chicago Press.

Hutcheon, L. (1994). Irony's edge: The theory and politics of irony. New York, NY: Routledge.

Comedians: Humor, Integrated. (1961, February 17). Time, p. 69.

Hyde, L. (1998). Trickster makes this world: Mischief, myth, and art. New York, NY: Farrar, Straus and Giroux.

Kastely, J. (1997). The Clouds: Aristophanic comedy and democratic education. Rhetoric Society Quarterly, 27(4), 25-46. DOI: 10.1080/02773949709391104

Kercher, S. E. (2007). Revel with a cause: Liberal satire in postwar America. Chicago, IL: University of Chicago Press. 
Lanham, R. A. (1976). Motives of eloquence: Literary rhetoric in the Renaissance. New Haven, CT: Yale University Press.

Lee, R. C. (1966). Dick Gregory goes fishing. The Nation, 202(17), 487-489.

McPhail, M. L. (2002). Rhetoric of racism revisted: Reparations or separation? Lanham, MD: Rowman \& Littlefield.

McPhail, M. L. (2004). A question of character: Re(-)signing the racial contract, Rhetoric \& Public Affairs, 7(3), 391-405.

Millstein, G. (1961, April 30). A Negro says it with jokes. New York Times, pp. 34, 37, 39-40.

Mintz, L. E. (ed.). (1988). Humor in America: A research guide to genres and topics. Westport, CT: Greenwood Press.

Nachman, G. (2003). Seriously funny: The rebel comedians of the 1950s and 1960s. New York, NY: Pantheon Books.

Park, J. H., Gabbadon, N. G., \& Chernin, A. R. (2006). Naturalizing racial difference through comedy: Asian, Black, and White views on racial stereotypes in Rush Hour 2. Journal of Communication, 56(1), 157-177. doi:10.1111/j.1460-2466.2006.00008.x

Poniewozik, J. (2007, March 8). Culture complex: Stand-up diplomacy. Time, p. 69. .

Poulakos, T. (1997). Speaking for the polis: Isocrates' rhetorical education. Columbia, SC: University of South Carolina Press.

Rossing, J. (2011). Comic provocations in racial culture: Barack Obama and the 'Politics of Fear'. Communication Studies, 62(4), 422-438. DOI: 10.1080/10510974.2011.588077

Rossing, J. (2012). Deconstructing Postracialism: Humor as a Critical, Cultural Project. Journal of Communication Inquiry, 36(1), 44-61. DOI: 10.1177/0196859911430753 
Rossing, J. P. (2014). Critical race humor in a postracial moment: Richard Pryor's contemporary parrhesia. The Howard Journal of Communications, 25(1), 16-33. DOI: $10.1080 / 10646175.2013 .857369$

Timmerman, D. M., Gussman, G. F., \& King, D. (2012). Humor, race and rhetoric: 'A liberating sabotage of the past's hold on the present.' Rhetoric Review, 31(2), 169-187. DOI: 10.1080/07350198.2012.652041

Smith, A. (1967, October 28). Look at this! The Milwankee Star, p. 13.

Watkins, M. (1994). On the real side: A history of African American comedy from Slavery to Chris Rock. Chicago, IL: Lawrence Hill Books.

Williams, J. (2000, October 19). Author, activist, and comedian Dick Gregory discusses his life and his views on social consciousness [Radio segment]. Talk of the Nation. Washington, DC: National Public Radio. 